\title{
Deskripsi Kemampuan Literasi Matematis Siswa Madrasah Tsanawiyah Negeri di Kota Kendari
}

\author{
Tandri Patih*), Luthfiah Jufri, Muhammad Febriawan, Nur Aini \\ Tadris Matematika Institut Agama Islam Negeri (IAIN) Kendari \\ Koresponden Autor:tandripatih@gmail.com; evyolet_8688@yahoo.co.id; \\ muhammad.febriawan21@gmail.com;nurainimtk@gmail.com
}

\begin{abstract}
Mathematical literacy is the ability to understand and use mathematics in various contexts to solve problems and be able to explain to others how to use mathematics. This study aims to describe the mathematical literacy skills of MTsN students in Kendari City. Data analysis was performed using descriptive statistics, i.e. by tabulating data and graphical methods. The results of the analysis show that overall, the percentage of mathematical literacy abilities of MTsN students in Kendari City is still dominated by groups of low-ability students. Based on the content, students' mathematical literacy ability is still low on content 2 . However, based on their categorization, students with a lower category of Mathematical Literacy Abilities are found in content 4 . When viewed based on the level, students get the lowest scores on level 6 questions. However, based on the categorization, students with a lower Mathematical Literacy Ability category are found in level 2 and level 4 questions. The school that was used as the object of the study was obtained that both based on the content and level, the mathematical literacy skills of grade IX MTsN 1 Kendari students were better than the IX grade students of MTsN 2 Kendari.
\end{abstract}

\section{Keywords: Mathematical Literacy Ability}

\begin{abstract}
Abstrak
Penelitian ini bertujuan untuk mendeskripsikan kemampuan literasi matematis siswa Madrasah Tsanawiyah Negeri di Kota Kendari. Analisis data dilakukan dengan menggunakan statistika deskriptif, yaitu dengan metode tabulasi data dan grafik statistik. Hasil analisis menunjukkan bahwa secara keseluruhan, persentase kemampuan literasi matematis siswa MTsN Kota Kendari masih didominasi oleh kelompok siswa yang berkemampuan rendah. Berdasarkan kontennya, kemampuan litearasi matematis siswa masih rendah pada konten 2 . Tetapi, jika dilihat berdasarkan pengkategoriannya, Siswa dengan kategori Kemampuan Literasi Matematis yang rendah lebih banyak terdapat pada konten 4. Jika dilihat berdasarkan levelnya, siswa memperoleh nilai paling rendah pada soal-soal level 6 . Namun, jika dilihat berdasarkan pengkategoriannya, siswa dengan kategori Kemampuan Literasi Matematis rendah lebih banyak terdapat pada soal level 2 dan level 4. Dengan membandingkan Kemampuan Literasi Matematis siswa pada dua sekolah yang dijadikan objek penelitian diperoleh bahwa baik berdasarkan konten maupun levelnya, kemampuan literasi matematis siswa kelas IX MTsN 1 Kendari lebih baik dibandingkan siswa kelas IX MTsN 2 Kendari.
\end{abstract}

\section{Kata Kunci: Kemampuan Literasi Matematis}




\section{A. PENDAHULUAN}

Pendidikan merupakan pondasi utama dalam mengembangkan sumber daya masyarakat sebagai upaya dalam membangun suatu bangsa dan negara. Pendidikan dapat membentuk kemampuan manusia, sehingga manusia mampu menggunakan nalarnya secara efektif dan efisien dalam menghadapi berbagai masalah yang timbul dalam usahanya untuk menggapai masa depan yang baik. Oleh karena itu, pendidikan merupakan kebutuhan yang sangat penting dalam kehidupan manusia sebab dapat dirasakan manfaatnya dalam segala segi kehidupannya. Undang-Undang No. 20 Tahun 2003 tentang sistem pendidikan nasional dalam pasal 39 ayat 2 , dinyatakan bahwa pendidik merupakan tenaga profesional yang bertugas merencanakan dan melaksanakan proses pembelajaran, menilai hasil pembelajaran, melakukan pembimbingan dan pelatihan, serta melakukan penelitian dan pengabdian kepada masyarakat, terutama bagi pendidik pada perguruan tinggi. Untuk itu diperlukan kemampuan dan profesional seorang guru dalam menentukan dan menerapkan berbagai komponen secara nyata dalam proses pembelajaran di sekolah.

Di tengah persaingan global, semakin tinggi kapabilitas dasar yang dimiliki suatu bangsa, semakin tinggi peluang untuk meningkatkan potensi Sumber Daya Manusia bangsa itu. Ironisnya kualitas pendidikan Indonesia oleh banyak kalangan dinilai masih rendah, khususnya dalam hal kualitas kemampuan matematika. Hal ini terlihat dari beberapa hasil survei yang dilakukan oleh lembaga-lembaga internasional seperti Trend in International Mathematics and Science Study (TIMSS) dan Program for International Student Assessment (PISA) yang menempatkan Indonesia pada posisi yang belum cukup memuaskan di antara negara-negara yang di survei. Hasil survei TIMSS tahun 2015 mencatat bahwa Indonesia menempati posisi ke 45 dari 50 Negara di bidang Matematika. ${ }^{1}$ Demikian pula PISA tahun 2015, yang mencatat bahwa Indonesia hanya menempati posisi ke 62 dari 70 Negara pada bidang literasi matematik. ${ }^{2}$

National Council of Teachers of Mathematics (NCTM) (2000), menetapkan lima standar kompetensi dalam pembelajaran matematika yaitu: pemecahan masalah matematis (mathematical problem solving), penalaran dan bukti (reasoning and proof), komunikasi (communication), koneksi (connections), dan representasi (representation). ${ }^{3}$ Kemampuan matematis lainnya yang lebih tinggi adalah kemampuan berpikir kritis matematis dan kemampuan berpikir kreatif matematis. ${ }^{4}$ Kelima kemampuan yang ditetapkan oleh NCTM sangatlah penting untuk dikuasai oleh peserta didik dalam memecahkan masalah yang dihadapai dalam kehidupan sehari-hari. Kelima kemampuan tersebut ditambah dengan kemampuan berpikir kreatif dan kritis matematis mampu mengembangkan potensi diri peserta didik untuk bias mengikuti dan bersaing dalam kehidupan di era globalisasi ini. Kemampuan literasi matematis adalah kemampuan yang mendukung pengembangan kelima kemampuan matematis yang dipaparkan oleh NCTM tersebut, yang kemudian diistilahkan sebagai daya matematis. ${ }^{5}$

\footnotetext{
${ }^{1}$ Ina V.S. Mullis, Michael O. Martin, Pierre Foy, dan Martin Hooper, TIMSS 2015 International Result in Mathematics. (IEA TIMSS \& PIRLS International Study Center, 2015), 14.

${ }^{2}$ OECD, PISA 2015 Result in Focus, (OECD, 2016), 16.

3 Masjaya dan Wardono. "Pentingnya Kemampuan LIterasi Matematika untuk Menumbuhkan Kemampuan Koneksi Matematika dalam Meningkatkan SDM". Prosiding dipresentasikan dalam Seminar Nasional Matematika UNNES 2017, Semarang, 21 Oktober 2017.

${ }^{4}$ Dr. H. Heris Hendriana, M.Pd., dan Prof. Dr. Hj. Utari Soemarmo, Penilaian Pembelajaran Matematika, (Bandung: PT. Refika Aditama, 2014), 19.

${ }^{5}$ Yunus Abidin, Tita Mulyati, dan Hana Yunansah, Pembelajaran Literasi, Strategi Meningkatkan Kemampuan Literasi Matematika, Sains, Membaca, dan Menulis, (Jakarta: Bumi Aksara, 2018), 99.
} 
Literasi (literacy) berasal dari bahasa latin Littera (huruf) yang pengertiannya melibatkan penguasaan system-sistem tulisan dan konvensi-konsvensi yang menyertainya. ${ }^{6}$ Literasi Matematis adalah kemampuan individu untuk merumuskan, menggunakan, dan menafsirkan matematika dalam berbagai konteks. Literasi Matematis mencakup penalaran matematis dan menggunakan konsep-konsep, prosedur, fakta, dan alat matematika untuk mendeskripsikan, menjelaskan, dan memprediksi suatu fenomena. Kemampuan ini membantu individu untuk mengakui bahwa matematika berperan di setiap aspek kehidupan dan untuk membuat keputusan yang beralasan dan juga dibutuhkan secara konstruktif, terlibat dan reflektif. ${ }^{7}$ Lebih jauh lagi, kemampuan literasi matematis membantu seseorang untuk memahami peran atau kegunaan matematika di dalam kehidupan sehari-hari sekaligus menggunakannya untuk membuat keputusan-keputusan yang tepat sebagai warga negara yang membangun, peduli, dan berpikir. ${ }^{8}$ Berdasarkan penjelasan tersebut, setiap guru/pendidik di bidang matematika dituntut menyiapkan peserta didiknya agar memiliki kemampuan Literasi Matematis yang baik, sehingga mampu menghadapi berbagai tantangan di era globalisasi masa mendatang.

PISA sebagai program yang dilaksanakan oleh OECD yang meneliti tentang kemampuan literasi matematika siswa yang berumur 15 tahun di 70 Negara membagi kemampuan (kecakapan) literasi matematis siswa menjadi enam tingkatan (level), yang ditunjukkan pada tabel 1 berikut: ${ }^{9}$

\section{Tabel 1; Deskripsi Skala/Level Kemampuan Literasi Matematis Menurut PISA}

\begin{tabular}{|c|c|}
\hline $\begin{array}{c}\text { Level } \\
6\end{array}$ & $\begin{array}{l}\text { Di level } 6 \text { ini, siswa dapat melakukan konseptualisasi dan generalisasi dengan } \\
\text { menggunakan informasi berdasarkan modelling dan penelaahan dalam suatu } \\
\text { situasi yang kompleks. Mereka dapat menghubungkan sumber informasi } \\
\text { berbeda dengan fleksibel dan menerjemahkannya. Siswa pada tingkatan ini } \\
\text { telah mampu berpikir dan bernalar secara matematika. Mereka dapat } \\
\text { menerapkan pemahamannya secara mendalam disertai dengan penguasaan } \\
\text { teknis operasi matematika, mengembangkan strategi dan pendekatan baru untuk } \\
\text { menghadapi situasi baru. Mereka dapat merumuskan dan mengkomunikasikan } \\
\text { apa yang mereka temukan. Mereka melakukan penafsiran dan berargumentasi } \\
\text { secara dewasa. }\end{array}$ \\
\hline $\mathrm{L}$ & $\begin{array}{l}\text { Di Level 5, siswa dapat bekerja dengan model untuk situasi yang kompleks, } \\
\text { mengetahui kendala yang dihadapi, dan melakukan dugaan-dugaan. Mereka } \\
\text { dapat memilih, membandingkan, dan mengevaluasi strategi untuk memecahkan } \\
\text { masalah yang rumit yang berhubungan dengan model ini. Siswa pada tingkatan } \\
\text { ini dapat bekerja dengan menggunakan pemikiran dan penalaran yang luas, } \\
\text { serta secara tepat menguhubungkan pengetahuan dan keterampilan }\end{array}$ \\
\hline
\end{tabular}

\footnotetext{
${ }^{6}$ Mahdiansyah dan Rahmawati. "Literasi Matematika Siswa Pendidikan Menengah: Analisis Menggunakan Desain Tes Internasional dengan Konteks Indonesia”. Jurnal Pendidikan dan Kebudayaan. Vol. 20, Nomor 4, (Desember, 2014): 454.

${ }^{7}$ Elsa Susanti dan Slamaini Safitri Syam, "Peran Guru dalam Meningkatkan Kemampuan Literasi Matematika Siswa Indonesia”. Prosiding dipresentasikan dalam Seminar Matematika dan Pendidikan Matematika UNY 2017, Yogyakarta, 11 Nopember 2017.

${ }^{8}$ Mega Nur Prabawati, "Analisis Kemampuan Literasi Mtematik Mahasiswa Calon Guru mAtematika", Jurnal "Mosharafa", Volume 7, Nomor 1,( Januari, 2018): 114.

${ }^{9}$ OECD, Mathematics Framework: Draft Subject to Possible revision after the Field Trial, (OECD, 2010), 27.
} 


\begin{tabular}{|c|c|}
\hline & $\begin{array}{l}\text { natikanya dengan situasi yang dihadapi. Mereka dapat melakukan refleksi } \\
\text { pa yang mereka kerjakan dan mengkomunikasikannya. }\end{array}$ \\
\hline $\begin{array}{r}\text { Lev } \\
4\end{array}$ & $\begin{array}{l}\text { Di level 4, siswa dapat bekerja secara efektif dengan model dalam situasi yang } \\
\text { konkret tetapi kompleks. Mereka dapat memilih dan mengintegrasikan } \\
\text { representasi yang berbeda, dan menghubungkannya dengan situasi nyata. Siswa } \\
\text { pada tingkatan ini dapat menggunakan keterampilannya dengan baik dan } \\
\text { mengemukakan alasan dan pandangan yang fleksibel sesuai dengan konteks. } \\
\text { Mereka dapat memberikan penjelasan dan mengkomunikasikannya disertai } \\
\text { argumentasi berdasar pada interpretasi dan tindakan mereka. }\end{array}$ \\
\hline $\begin{array}{c}\text { Lev } \\
3\end{array}$ & $\begin{array}{l}\text { Dilevel 3, siswa dapat melaksanakan prosedur dengan baik, termasuk prosedur } \\
\text { yang memerlukan keputusan secara berurutan. Mereka dapat memilih dan } \\
\text { menerapkan strategi memecahkan masalah yang sederhana. Siswa pada } \\
\text { tingkatan ini dapat menginterpretasikan dan menggunakan representasi } \\
\text { berdasarkan sumber informasi yang berbeda dan mengemukakan alasannya. } \\
\text { Mereka dapat mengkomunikasikan hasil interpretasi dan alasan mereka. }\end{array}$ \\
\hline $\begin{array}{c}\text { Level } \\
2\end{array}$ & $\begin{array}{l}\text { wa pada tingkatan ini dapat mengerjakan algoritma dasar, mengg } \\
\text { nus, melaksanakan prosedur atau konvensi sederhana. Mereka } \\
\text { mberikan alasan secara langsung dan melakukan penafsiran harfiah. }\end{array}$ \\
\hline $\begin{array}{r}\text { Lev } \\
1\end{array}$ & $\begin{array}{l}\text { Dilevel 1, siswa dapat menjawab pertanyaan yang konteksnya umum dan } \\
\text { dikenal serta semua informasi yang relevan tersedia dengan pertanyaan yang } \\
\text { jelas. Mereka dapat mengidentifikasi informasi dan menyelesaikan prosedur } \\
\text { rutin menurut instruksi eksplisit. Mereka dapat melakukan tindakan sesuai } \\
\text { dengan stimuli yang diberikan. }\end{array}$ \\
\hline
\end{tabular}

Setiap level pada tabel 1 di atas menunjukkan tingkat kompetensi (kecakapan) matematika yang diharapkan dapat dicapai oleh para siswa. Level 6 merupakan tingkatan pencapaian yang tertinggi, sedangkan level 1 merupakan tingkatan pencapaian siswa yang paling rendah. Semakin tinggi level, semakin kompleks pengetahuan yang diperlukan untuk menjawab persoalan yang diberikan. Soal yang peling mudah disusun untuk mengetahui pencapaian peserta didik dalam kompetensi reproduksi, sedangkan soal yang sulit dibuat untuk menguji kompetensi refleksi dan disusun sedemikian rupa dengan konteks yang paling sederhana. ${ }^{10}$ Selanjutnya, OECD (2010), Hayat dan Yusuf (2010) menjelaskan bahwa, dalam kerangka soal PISA, soal digolongkan dalam tiga domain utama, yaitu kategori konteks, konten dan proses. Konteks matematika dalam PISA dapat dikategorikan menjadi empat konteks, yaitu: a) Personal (konteks pribadi), b) Occupational (konteks pekerjaan), c) Societal (konteks umum), d) Scientific (konteks ilmiah). Kategori konten dalam PISA dibagi menjadi empat yaitu: 1) Change and Relationships (Perubahan dan Hubungan), 2) Space and Shape (Ruang dan Bentuk), 3) Quantity (Bilangan), 4) Uncertainty and Data (Probabilitas/Ketidakpastian dan Data). ${ }^{11}$

\footnotetext{
${ }^{10}$ Qasim, Kadir dan Awaluddin, "Deskripsi Kemampuan Literasi Matematika Siswa SMP Negeri di Kabupaten Buton Utara", Jurnal Penelitian Pendidikan Matematika, Volume 3, No. 3, (Mei, 2015): 98.

${ }^{11}$ Agus Maulana dan Hasnawati, "Deskripsi Kemampuan Literasi MAtematika Siswa Kelas VIII-2 SMP Negeri 15 Kendari”, Jurnal Pendidikan Matematika, Volume 4, No. 2, (Mei, 2016):3.
} 
Kemampuan literasi matematis dianggap sebagai salah satu komponen penting yang dibutuhkan siswa untuk dapat berhasil memecahkan soal-soal PISA. Kemampuan ini juga berfokus kepada kemampuan siswa dalam menganalisis, memberikan alasan, dan menyampaikan ide secara efektif, merumuskan, memecahkan, dan menginterpretasi masalah-masalah matematika dalam berbagai bentuk dan situasi. Pentingnya Literasi Matematis ini, ternyata belum sejalan dengan prestasi siswa Indonesia dimata internasional. Fakta masih terpuruknya kecakapan anak-anak usia 15 tahun dalam mengimplementasikan masalah-masalah dikehidupan nyata, sebagaimana ditunjukkan dengan hasil studi PISA, tentu menjadi persoalan serius yang harus disikapi dunia pendidikan nasional. Lebih lanjut lagi, berdasarkan hasil penelitian yang dilakukan oleh Mahdiansyah dan Rahmawati (2014), diketahui bahwa dari 7 sampel daerah yang diamati (Bandung, Kendari, Kupang, Medan, Palembang, Samarinda dan Yogyakarta), skor terendah dicapai oleh siswa SMA/MA yang berasal dari kota Kendari dengan skor 19.4, yang berarti masih berada tiga standar deviasi di bawah rerata skala (sebesar 50.0). ${ }^{12} \mathrm{Hal}$ ini menjelaskan bahwa, diantara ketujuh daerah tersebut Kemampuan Literasi Matematika Siswa di Kota Kendari masih cukup memprihatinkan. Rendahnya capaian siswa SMA/MA di kota Kendari pada hasil penelitian tersebut, bisa jadi sebagai dampak lebih lanjut dari rendahnya kemampuan literasi matematis siswa di SMP/MTs. Seperti hasil penelitian yang dilakukan oleh Maulana dan Hasnawati (2016), yang mengungkapkan bahwa siswa di SMP Negeri 15 Kendari mengalami kesulitan dalam menyelesaikan materi soal matematika yang diteskan, khususnya pada materi perbandingan. ${ }^{13}$ Melihat masalah yang telah dikemukakan di atas dan juga hasil-hasil penelitian yang telah dipaparkan, maka penulis kemudian juga merasa perlu untuk memperoleh deskripsi Kemampuan Literasi Matematis siswa Madrasah Tsanawiyah Negeri di Kota Kendari Tahun Ajaran 2018/2019, yang dianalisis menggunakan statistika deskriptif dengan metode tabulasi data dan grafik statistik.

Penelitian ini merupakan penelitian kualitatif deskriptif, yang bertujuan memberikan gambaran deskripsi kemampuan literasi matematis siswa Madrasah Tsanawiyah Negeri (MTsN) di Kota Kendari Tahun Ajaran 2018/2019. Data yang digunakan dalam penelitian ini merupakan data primer yang diperoleh dari hasil tes yang dilakukan pada siswa Kelas IX Madrasah Tsanawiyah Negeri (MTsN) di Kota Kendari (yakni: MTsN 1 Kendari dan MTsN 2 Kendari), semester ganjil tahun ajaran 2018/2019. Pemilihan sampel dilakukan dengan teknik cluster random sampling. Metode Cluster Random Sampling digunakan untuk menentukan jumlah sampel kelas pada masing-masing sekolah. Data dalam penelitian ini dikumpulkan menggunakan instrument berupa tes uraian Kemampuan Literasi Matematis yang diadaptasi dari soal PISA. Data yang dikumpulkan kemudian dianalisis menggunakan statistika deskriptif untuk mengidentifikasi dan memberikan gambaran kemampuan literasi matematis siswa kelas IX MTsN di kota Kendari.

\section{B. HASIL PENELITIAN DAN PEMBAHASAN}

\section{Deskripsi Kemampuan Literasi Matematis Siswa Madrasah Tsanawiyah Negeri secara Keseluruhan}

\footnotetext{
${ }^{12}$ Mahdiansyah dan Rahmawati, op.cit., 458.

13 Agus Maulana dan Hasnawati, op.cit., 9-10.
} 
Pada bagian ini akan disajikan karakteristik siswa Madrasah Tsanawiyah Negeri (MTsN) di Kota Kendari berdasarkan Asal Sekolahnya, serta Kemampuan Literasi Matematis Siswa MTsN secara keseluruhan. Berikut adalah karakteristik siswa MTsN di Kota Kendari semeter Ganjil Tahun Ajaran 2018/2019.

Tabel 2; Karakteristik siswa Madrasah Tsanawiyah Negeri (MTsN) di Kota Kendari semester Ganjil Tahun Ajaran 2018/2019

\begin{tabular}{cccc}
\hline \multirow{2}{*}{ Sekolah } & \multicolumn{2}{c}{ Jenis Kelamin } & \multirow{2}{*}{ Jumlah } \\
\cline { 2 - 3 } & Laki-Laki & Perempuan & Siswa \\
\hline MTs Negeri 1 Kendari & 17 & 45 & 62 \\
\hline MTs Negeri 2 Kendari & 18 & 43 & 61 \\
\hline Total & 35 & 88 & 123 \\
\hline
\end{tabular}

Berdasarkan Tabel 2 diketahui bahwa jumlah siswa Madrasah Tsanawiyah Negeri (MTsN) di Kota Kendari yang terdiri dari 2 Madrasah yaitu, MTsN 1 Kendari dan MTsN 2 Kendari yang dijadikan sebagai sampel keseluruhan berjumlah 123 siswa. Siswa MTsN 1 Kendari berjumlah 62 siswa yakni yakni sebanyak 45 siswa perempuan dan sebanyak 17 siswa laki-laki, kemudian MTsN 2 Kendari berjumlah 61 siswa yakni sebanyak 43 siswa perempuan dan sebanyak 18 siswa laki-laki.

Jika kemampuan siswa dikelompokkan menurut kategori tinggi (Nilai $\geq$ mean + 0.5·Standar Deviasi), sedang (mean $-0.5 \cdot$ Standar Deviasi $\leq$ Nilai $<$ mean $+0.5 \cdot$ Standar Deviasi) dan rendah (mean - 0.5Standar Deviasi < Nilai), Deskripsi persentase Kemampuan Literasi Matematis siswa Madrasah Tsanawiyah Negeri di Kota Kendari dapat disajikan dalam tabel 3 berikut ini:

Tabel 3; Persentase Kemampuan Literasi Matematis siswa Madrasah Tsanawiyah Negeri di Kota Kendari Tahun Ajaran 2018/2019

\begin{tabular}{ccc}
\hline Kemampuan & Jumlah & Persentase \\
\hline Tinggi & 35 & $28 \%$ \\
Sedang & 42 & $34 \%$ \\
Rendah & 46 & $37 \%$ \\
\hline
\end{tabular}

Berdasarkan Tabel 3 terlihat bahwa siswa Madrasah Tsanawiyah Negeri di Kota Kendari lebih banyak memiliki Kemampuan Literasi Matematis yang rendah yaitu sebanyak 48 siswa (atau sebesar 37\%) kemudian berturut-turut diikuti oleh siswa yang memiliki Kemampuan Literasi Matematis yang sedang, yaitu sebanyak 42 siswa (atau sebesar 34\%), dan Kemampuan Literasi Matematis yang tinggi yaitu sebanyak 35 siswa (atau sebesar 28\%). Dari tabel 2, dapat diketahui bahwa persentase kemampuan literasi matematis siswa di MTsN Kota Kendari secara keseluruhan masih didominasi oleh kelompok siswa yang berkemampuan rendah. Hasil ini serupa dengan kasus yang diteliti 
oleh Siswowijoyo dan Kadir Tiya (2014), yang memaparkan bahwa rata-rata perolehan nilai kemampuan literasi matematis siswa SMP Negeri di Kota Raha Sulawesi Tenggara masih tergolong rendah. ${ }^{14}$

Seperti yang dipaparkan pada bagian pendahuluan, bahwa deskripsi kemampuan literasi matematis oleh PISA dibagi menjadi 6 level kemampuan, yang kemudian dalam penelitian ini dituangkan kedalam soal kemampuan literasi matematik. Diagram Rata-rata Kemampuan Literasi Matematis per Levelnya Siswa MTsN di Kota Kendari, dapat dilihat pada diagram berikut ini:

Tabel 4; Karakteristik Kemampuan Literasi Matematis siswa MTsN di Kota Kendari per Level Kemampuan Literasi Matematis Tahun Ajaran 2018/2019

\begin{tabular}{cccccccc}
\hline \hline Level & $\begin{array}{c}\text { Skor Maks } \\
\text { Soal }\end{array}$ & $\begin{array}{c}\text { Nilai } \\
\text { Maks }\end{array}$ & $\begin{array}{c}\text { Nilai } \\
\text { Min }\end{array}$ & Mean & Modus & Median & $\begin{array}{c}\text { Standar } \\
\text { Deviasi }\end{array}$ \\
\hline \hline 1 & 10 & 9 & 2 & 7.48 & 8 & 8 & 1.49 \\
2 & 10 & 9 & 0 & 4.15 & 2 & 4 & 2.01 \\
3 & 15 & 14 & 0 & 4.59 & 3 & 3 & 3.10 \\
4 & 5 & 5 & 0 & 1.69 & 1 & 1 & 1.60 \\
5 & 5 & 4 & 0 & 1.27 & 1 & 1 & 1.57 \\
6 & 10 & 10 & 0 & 1.46 & 2 & 2 & 1.46 \\
\hline \hline
\end{tabular}

Jika melihat nilai maksimum pada tabel 4 di atas, dapat diketahui bahwa terdapat siswa di MTsN Kota Kendari yang memperoleh skor/nilai sempurna untuk kemampuan literasi matematik pada level 4 dan 10, hampir sempurna di level soal yang lain. Namun, jika dilihat berdasarkan nilai minimum pada tabel 4 tersebut, diketahui bahwa terdapat siswa yang sama sekali tidak dapat memberikan jawaban atau memberikan jawaban salah untuk soal kemampuan literasi matematik pada level 2, 3, 4, 5, dan 6. Sedangkan pada level 1, siswa secara keseluruhan telah mampu menjawab permasalahan yang diberikan, walaupun masih ada yang memiliki nilai terendah 2 yang sangat jauh dibawah nilai mean. Tabel 4 menunjukkan nilai mean kemampuan literasi matematis siswa MTsN di kota Kendari terbesar yaitu berada pada level 1 yakni sebesar 7.48 dari skor maksimal 10. Ini menunjukkan bahwa kemampuan literasi matematis siswa di level 1 sudah termasuk pada kategori yang memuaskan. Namun, tidak demikian dengan level kemampuan literasi yang lain. Dari tabel 4, terlihat bahwa nilai mean level 2 sampai level 6, jauh dibawah skor maksimum soal, terutama pada level 6. Rendahnya nilai mean yang jauh dari skor maksimum soal, mengindikasikan bahwa kemampuan literasi siswa pada level ini masih teramat rendah. Selanjutnya, jika dilihat dari nilai standar deviasinya, kemampuan literasi matematis siswa pada soal level 6 terlihat sangat rendah dibanding level lainnya. Ini menunjukkan bahwa persebaran/keragaman siswa dalam menjawab soal tersebut sangatlah rendah (tidak beragam), dimana jika melihat kembali nilai meannya, rata-rata kemampuan literasi matematis siswa pada level 6 sangatlah rendah. Hal ini, berarti bahwa secara keseluruhan kemampuan literasi siswa pada level 6 sangat rendah dan hampir semua memiliki nilai yang seragam. Jika diamati lebih jauh lagi, semua nilai standar

\footnotetext{
${ }^{14}$ Mia Siswowijoyo dan Kadir Tiya, "Deskripsi Kemampuan Literasi Matematika Siswa Kelas IX SMP Negeri di Kota Raha”, Jurnal Penelitian Pendidikan Matematika, Volume 2, No. 2, (Mei, 2014): 84-85.
} 
deviasi pada tiap level soal terlihat rendah, sehingga dapat dikatakn bahwa secara keseluruhan kemampuan literasi matematis siswa disetiap level soal hampir seragam.

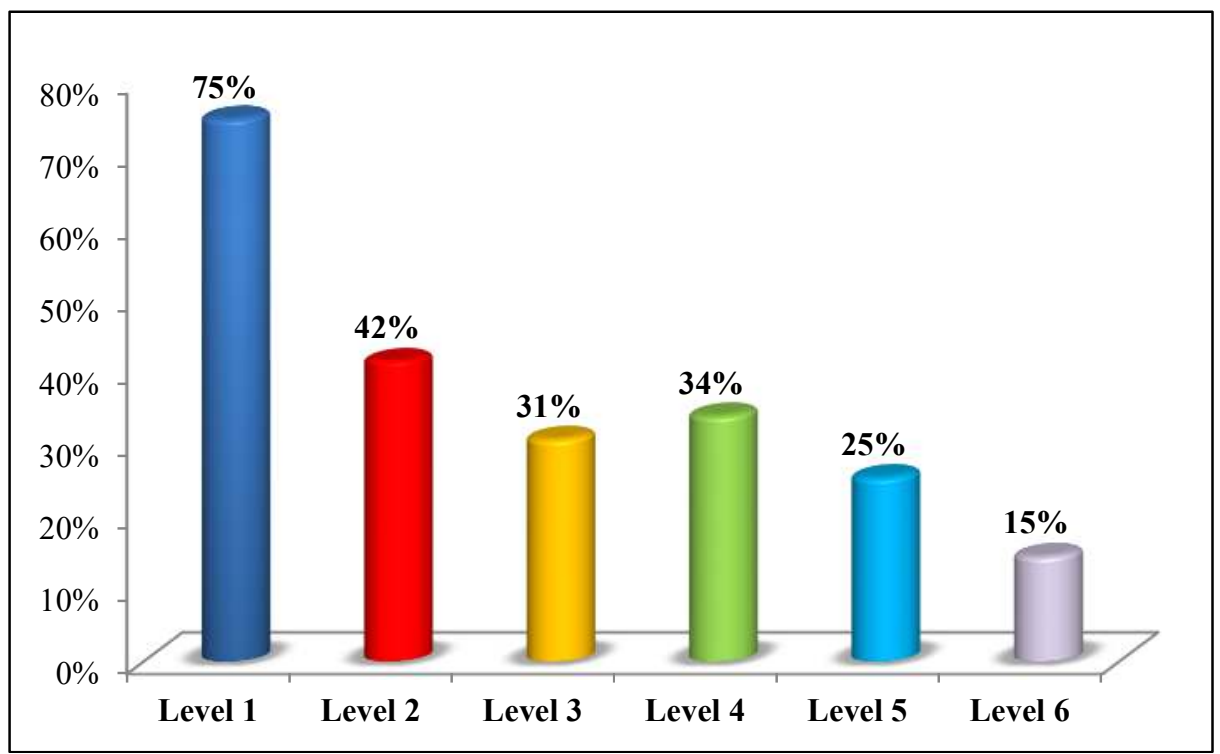

Gambar 1; Rata-rata Kemampuan Literasi Matematis Siswa MTsN di Kota Kendari Per Level Kemampuan Literasi Matematis

Berdasarkan Gambar 1 dapat dilihat bahwa rata-rata kemampuan Literasi Matematis siswa di MTsN Kota Kendari pada level 1 sebesar 75\% dari total skor maksimal yang diharapkan, atau dengan kata lain siswa MTsN di Kota Kendari mampu menyelesaikan soal level 1 Kemampuan Literasi Matematis dengan rata-rata keseluruhan sebesar 7,5 dari total skor yang diharapkan yakni sebesar 10. Pada level 2, 3, 4, 5, dan 6 berturut-turut sebesar $42 \%, 31 \%, 34 \%, 25 \%$ dan $15 \%$ dari total skor maksimal yang diharakan untuk masing-masing level Kemampuan Literasi Matematis. Jika dirataratakan, perolehan siswa untuk keseluruhan level sebesar 35\% dari total skor maksimal keseluruhan. Artinya, secara keseluruhan rata-rata kemampuan Literasi Matematis siswa belum mencapai setengah dari total skor kemampuan Literasi Matematis standar PISA yang diharapkan dari keseluruhan soal.

Dari hasil pencapaian tersebut dapat dilihat bahwa kemampuan siswa pada tingkatan level 1 ke level 3 mengalami penurunan yang artinya semakin tinggi level soal semakin rendah pula kemampuan yang diperoleh siswa, begitu pula pada tingkatan level 4 ke 6 yang mengalami penurunan. Namun pada level 3 ke level 4 mengalami peningkatan persentase. Walaupun tingkatan soal pada level 4 semakin rumit, siswa mampu menginterpretasikan dan menyelesaikan masalah setingkat lebih baik dibandingkan dengan soal pada level 3. Hasil ini sejalan dengan hasil yang dikemukakan oleh Maulana dan Hasnawati (2016), yang juga menemukan bahwa kemampuan literasi matematis siswa SMP Negeri 15 Kendari menurun ketika dihadapkan pada soal berlevel 2 dan 3 dibanding soal level 1, namun naik mengalami kenaikan pada soal level ke 4 dan 5 dibanding sola dengan level 3. ${ }^{15}$ Hal ini juga menjelaskan bahwa rata-rata siswa, telah mampu menggunakan keterampilannya dengan baik dan mengemukakan alasan/pandangan yang

${ }^{15}$ Agus Maulana dan Hasnawati, op.cit., 7. 
fleksibel sesuai dengan konteks soal yang diberikan, walaupun belum cukup memuaskan secara keseluruhan. Dilihat dari level Kemampuan Literasi Matematis, soal pada level 3 memiliki tingkat kesulitan yang lebih rendah dibandingkan soal pada level 4. Soal pada level 3 mengharuskan siswa untuk dapat mengkomunikasikan hasil interpretasi dan alasan mereka, sedangkan pada level 4 siswa dituntut untuk dapat memberikan penjelasan, mengkomunikasikannya disertai argumentasi yang berdasarkan pada interpretasi dan tindakan mereka.

Adanya perbedaan persentase level Kemampuan Literasi Matematis tersebut dapat disebabkan oleh jumlah soal yang tidak sebanding pada level 3 dan level 4, dimana soal pada level 3 ada sebanyak 2 soal dan pada level 4 sebanyak 1 soal. Faktor lain juga dapat disebabkan penggunaan konten dan redaksi soal yang digunakan pada soal. Pada soal level 3 redaksi soal menggunakan kalimat yang lebih panjang dibandingkan dengan soal level 4 yang hanya menggunakan gambar, walaupun konsep matematika yang digunakan itu lebh mudah tetapi rata-rata siswa cenderung kurang berminat menyelesaikan soal yang berbentuk cerita. Perolehan rata-rata kemampuan siswa pertingkatan level juga tidak dapat dilepaskan dari kemampuan dasar matematika siswa yang berbeda-beda serta kemampuan siswa dalam memahami konteks, konten dan proses yang melekat pada soal. Jika ditinjau dari segi kemampuan individu dalam menyelesaikan soal secara keseluruhan ada beberapa siswa yang memperoleh nilai tinggi untuk level 1, namun dalam menyelesaikan soal secara keseluruhan, siswa yang memperoleh nilai paling rendah yaitu pada soal-soal level 6.

Jika Kemampuan Literasi Matematis siswa perlevelnya dibagi menjadi kategori tinggi (Nilai $\geq \bar{X}+0.5 \cdot$ Standar Deviasi), sedang $(\bar{X}-0.5 \cdot$ Standar Deviasi $\leq$ Nilai $<\bar{X}+$ $0.5 \cdot$ Standar Deviasi) dan rendah $(\bar{X}-0.5 \cdot$ Standar Deviasi $<$ Nilai $)$ dari skor Kemampuan Literasi Matematis siswa, persentase kemampuan siswa dapat dilihat pada grafik berikut:

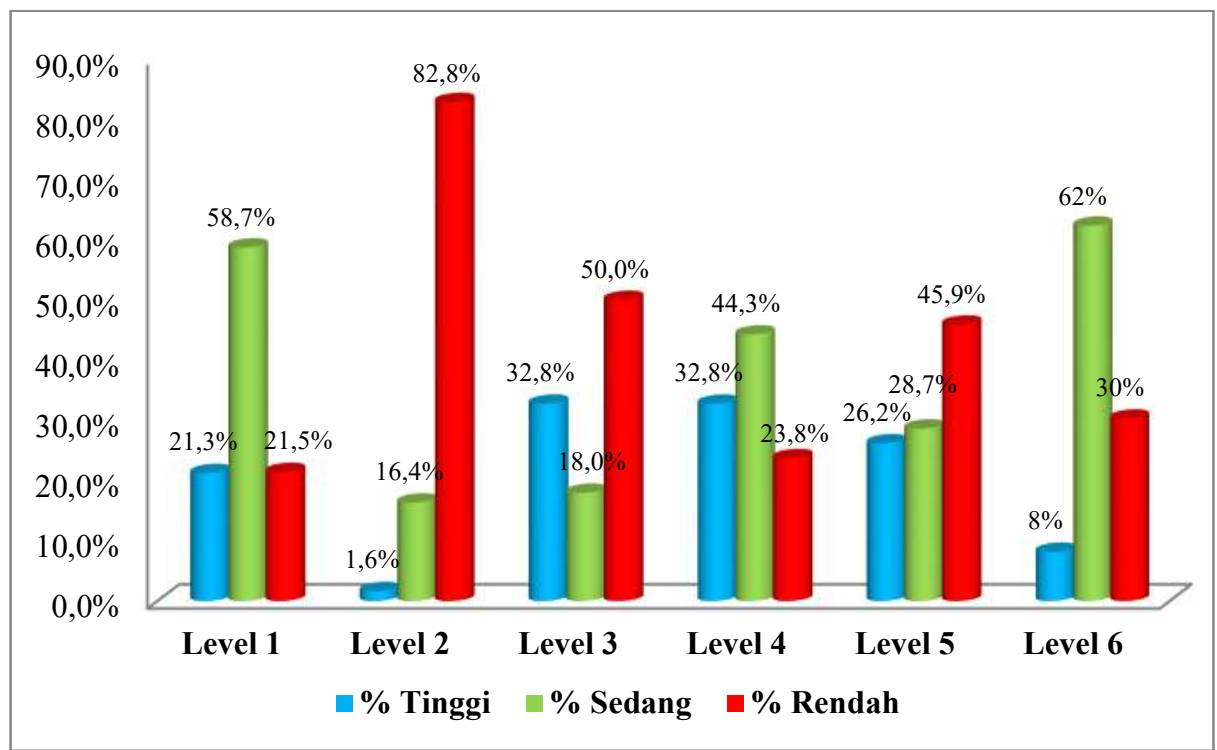

Gambar 2; Persentase Kemampuan Literasi Matematis siswa MTsN berdasarkan Level Kemampuan Literasi Matematis

Berdasarkan nilai rata-rata dan standar deviasinya persentase Kemampuan Literasi Matematis siswa pada level 1 dengan kategori kemampuan sedang yakni 
sebanyak 58\%, kemudian berturut-turut siswa dengan kategori kemampuan tinggi dan rendah memiliki persentase yang sama yakni sebanyak $21 \%$. Persentase Kemampuan Literasi Matematis siswa yang berada pada level 2 dengan kategori kemampuan rendah yakni sebanyak 83\%, kemudian berturut-turut siswa dengan kategori kemampuan sedang yakni sebanyak $16 \%$ dan siswa dengan kategori kemampuan tinggi yakni sebanyak 1\%, hal ini menunjukan bahwa siswa memiliki Kemampuan Literasi Matematis Level 1 yang rendah. Persentase Kemampuan Literasi Matematis siswa yang berada pada level 3 dengan kategori kemampuan rendah yakni sebanyak 50\%, kemudian berturut-turut siswa dengan kategori kemampuan tinggi yakni sebanyak 32\% dan siswa dengan kategori kemampuan tinggi sedang sebanyak 18\%. Persentase Kemampuan Literasi Matematis siswa yang berada pada level 4 dengan kategori kemampuan sedang yakni sebanyak $44 \%$, kemudian berturut-turut siswa dengan kategori kemampuan tinggi yakni sebanyak $32 \%$ dan siswa dengan kategori kemampuan rendah yakni sebanyak $24 \%$, hal ini menunjukan bahwa siswa memiliki Kemampuan Literasi Matematis Level 4 yang sedang. Persentase Kemampuan Literasi Matematis siswa yang berada pada level 5 dengan kategori kemampuan rendah yakni sebanyak 46\%, kemudian berturutturut siswa dengan kategori kemampuan sedang yakni sebanyak $28 \%$ dan siswa dengan kategori kemampuan tinggi yakni sebanyak 26\%, hal ini menunjukan bahwa siswa memiliki Kemampuan Literasi Matematis Level 5 yang rendah. Persentase Kemampuan Literasi Matematis siswa yang berada pada level 6 kategori kemampuan sedang yakni sebanyak $62 \%$, kemudian berturut-turut siswa dengan kategori kemampuan rendah yakni sebanyak 30\% dan siswa dengan kategori kemampuan tinggi yakni sebanyak $8 \%$, hal ini menunjukan bahwa siswa memiliki Kemampuan Literasi Matematis Level 6 yang sedang. Gambar 2 juga menunjukkan bahwa siswa dengan kategori Kemampuan Literasi Matematis yang rendah lebih banyak terdapat pada soal level 2 dan paling sedikit terdapat pada soal level 1. Ini berarti bahwa, secara keseluruhan siswa telah mampu untuk menyelesaikan soal-soal kemampuan literasi matematis berlevel 1. Hasil tersebut serupa dengan hasil yang dikemukakan oleh Khoirudin, dkk. (2017), yang mengungkapkan bahwa siswa berkemampuan matematis rendah hanya mampu menyelesaikan masalah/soal kemampuan literasi matematis dengan tingkatan level $1 .{ }^{16}$ Persebaran persentase kemampuan literasi matematis siswa pada soal level 1 ini pun terlihat normal secara visual (berdasarkan grafik), dimana siswa dengan kemampuan literasi matematis yang tinggi sebanding dengan siswa dengan kemampuan literasi matematis yang rendah, dan lebih didominasi oleh siswa dengan kemampuan literasi matematis yang sedang.

Deskripsi persentase hasil tes Kemampuan Literasi Siswa Kelas IX MTsN Kendari dilihat dari Konten Kemampuan Literasi Matematis, yang terdiri dari 1) Konten 1: Ketidakpastian dan Data (Uncertainty and Data); 2) Konten 2: Ruang dan Bentuk (Space and Shape); 3) Konten 3: Kuantitas (Quantity); 4) Konten 4: Perubahan dan Keterkaitan (Change and Relationship), dapat dilihat pada diagram berikut ini:

\footnotetext{
${ }^{16}$ Ahmad Khoirudin, Rina Dwi Setyawati, dan Farida Nuryahida, "Profil Kemampuan Literasi Matematika Siswa Berkemampuan Matematis Rendah Dalam Menyelesaikan Soal Berbentuk PISA", Aksioma, Vol. 8, No. 2, (November, 2017): 39.
} 
Al Izzah: Jurnal Hasil-Hasil Penelitian-ISSN: 1978-9726 (p); 2541-0717 (e)

Volume 14, Nomor 1 (Mei, 2019)

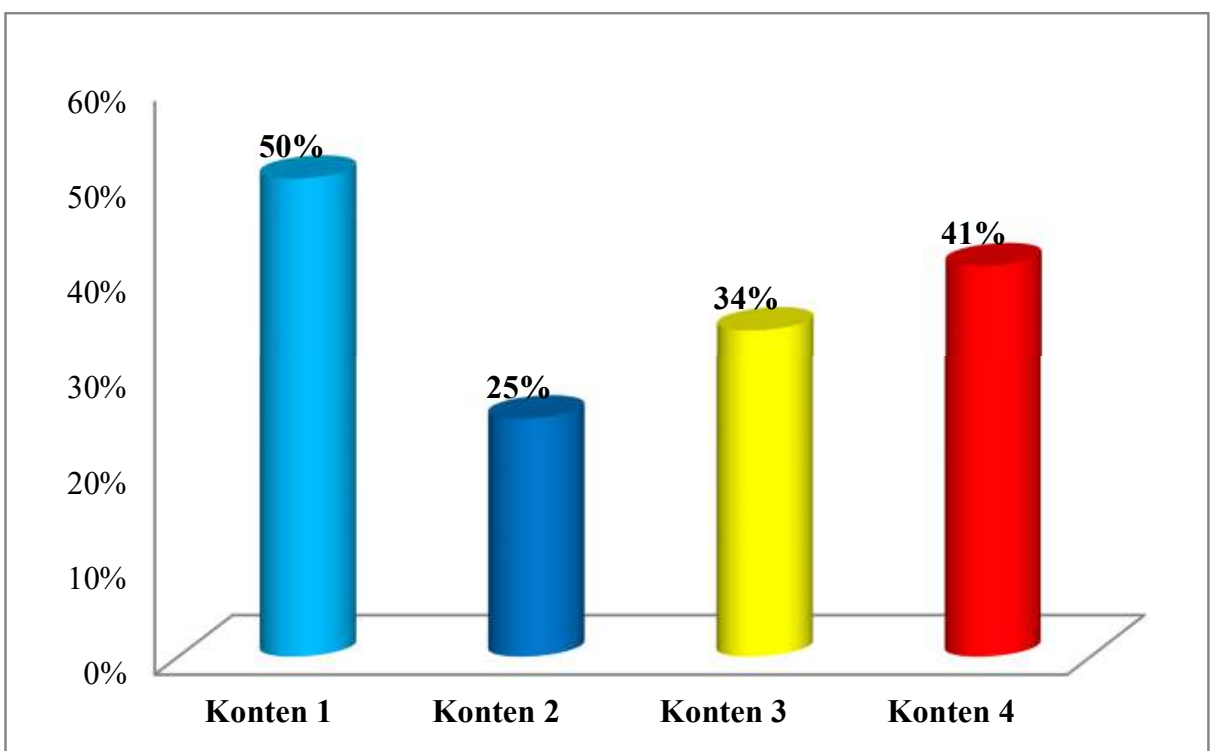

Gambar 3; Rata-rata Kemampuan Literasi Matematis Siswa MTsN di Kota Kendari Berdasarkan Konten Kemampuan Literasi Matematis

Berdasarkan Gambar 3 dapat dilihat bahwa rata-rata kemampuan literasi matematis siswa di MTsN Kota Kendari pada soal Konten 1 sebesar 50\% dari total skor maksimal yang diharapkan. Pada level 2, 3, dan 4 berturut-turut sebesar 25\%, 34\%, dan $41 \%$ dari total skor maksimal yang diharakan untuk masing-masing konten Kemampuan Literasi Matematis. Jika dirata-ratakan, perolehan siswa untuk keseluruhan konten yaitu sebesar 43,75\% dari total skor maksimal keseluruhan. Artinya, secara keseluruhan rata-rata kemampuan literasi matematis siswa belum mencapai setengah dari total skor soal kemampuan literasi matematis standar PISA yang diharapkan. Secara keseluruhan siswa banyak yang dapat menjawab soal konten 1, dan paling sedikit yang dapat menjawab soal dengan konten 2 . Soal konten 1 adalah soal yang berkaitan dengan Ketidakpastian dan Data (Uncertainty and Data) yaitu soal yang menguji siswa dalam membaca dan menginterpretasikan data dalam diagram dan tabel, serta pola bilangan. Kemudian soal konten 2 adalah soal yang berkaitan dengan Ruang dan Bentuk (Space and Shape), yaitu soal yang menguji siswa dalam membaca bentuk dan pola dari suatu bangun geometri.

Jika Kemampuan Literasi Matematis siswa perkontennya dibagi menjadi kategori tinggi (Nilai $\geq$ mean $+0,5 \cdot$ Standar Deviasi), sedang (mean - 0,5·Standar Deviasi $\leq$ Nilai $<$ mean $+0,5 \cdot$ Standar Deviasi) dan rendah (mean $-0,5 \cdot$ Standar Deviasi $<$ Nilai), persentase kemampuan siswa dapat dilihat pada grafik berikut: 
Al Izzah: Jurnal Hasil-Hasil Penelitian-ISSN: 1978-9726 (p); 2541-0717 (e)

Volume 14, Nomor 1 (Mei, 2019)

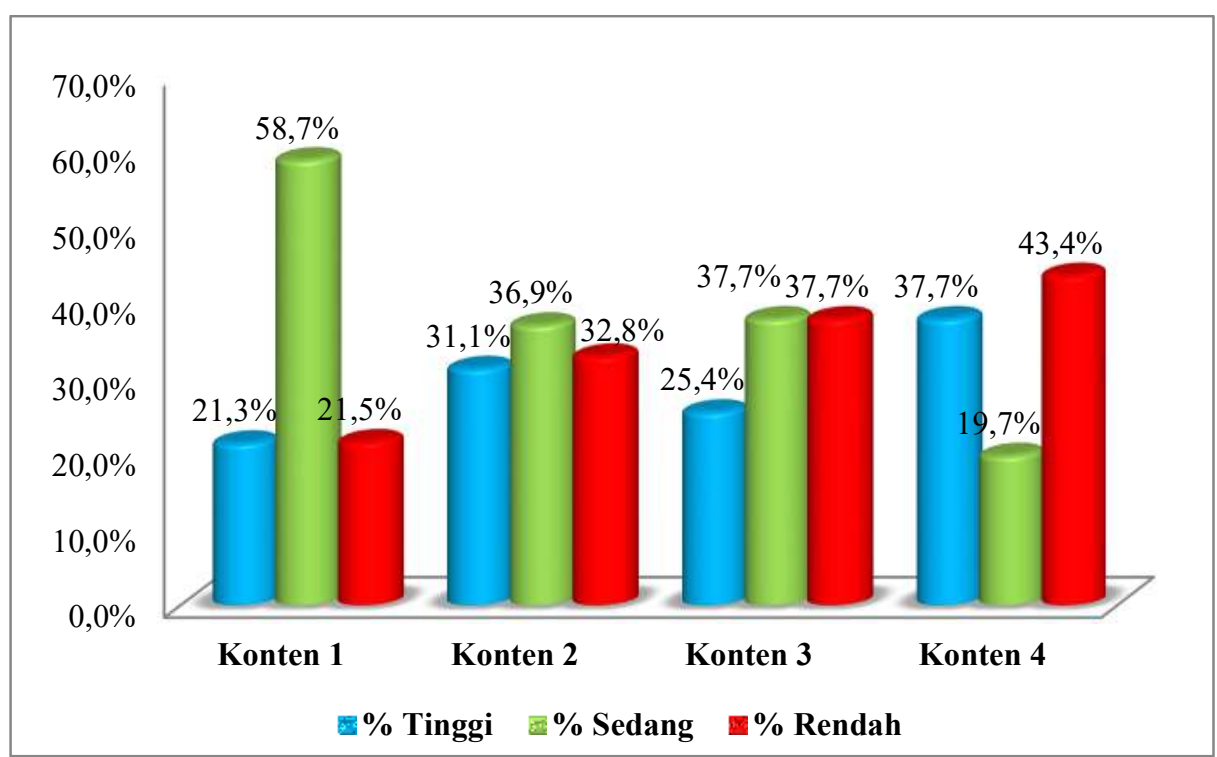

Gambar 4; Rata-rata Kemampuan Literasi Matematis Siswa MTsN di Kota Kendari Per Konten Kemampuan Literasi Matematis

Berdasarkan Gambar 4, nilai rata-rata dan standar deviasinya persentase Kemampuan Literasi Matematis siswa per kontennya, diketahui bahwa persentase Kemampuan Literasi Matematis siswa dengan kategori kemampuan sedang yang menjawab soal konten 1 yakni sebesar $58,7 \%$. Kemudian berturut-turut siswa dengan kategori kemampuan tinggi dan rendah memiliki persentase sebesar $21,3 \%$ dan $21,5 \%$. Persentase Kemampuan Literasi Matematis siswa dengan kategori kemampuan rendah yang yang menjawab soal konten 2 sebesar $32.8 \%$, kemudian berturut-turut siswa dengan kategori kemampuan sedang yakni sebesar 36,9\% dan siswa dengan kategori kemampuan tinggi yakni sebesar 31,1\%. Selanjutnya, persentase Kemampuan Literasi Matematis siswa yang menjawab soal konten 3 dengan kategori kemampuan rendah dan sedang memiliki persentase yang sama yakni sebesar $37.7 \%$. Kemudian siswa dengan kategori kemampuan tinggi yakni sebesar 25.4\%. Kemudian persentase Kemampuan Literasi Matematis siswa yang menjawab soal konten 4 didominasi oleh siswa dengan kategori kemampuan rendah yakni sebanyak 43,4\%, kemudian berturut-turut siswa dengan kategori kemampuan tinggi yakni sebanyak 37,7\% dan siswa dengan kategori kemampuan sedang yakni sebanyak 19,7\%. Hal ini menjelaskan bahwa, berdasarkan konten soalnya, siswa lebih banyak berada pada kelompok dengan kategori Kemampuan Literasi Matematis yang sedang untuk konten Ketidakpastian dan Data, serta Ruang dan Bentuk. Gambar 4 juga menjelaskan bahwa siswa dengan kategori Kemampuan Literasi Matematis yang rendah lebih banyak terdapat pada konten Perubahan dan Keterkaitan. Ini berarti, soal-soal Kemampuan Literasi Matematis yang berkaitan dengan perubahan dan keterkaitan seperti soal-soal perbandingan dan aljabar masih menjadi soal yang sulit untuk siswa selesaikan.

\section{Deskripsi Kemampuan Literasi Matematis siswa di Madrasah Tsanawiyah Negeri (MTsN) 1 Kendari dan Madrasah Tsanawiyah Negeri (MTsN) 2 Kendari}


Pada bagian ini akan disajikan karakteristik Kemampuan Literasi Matematis Siswa MTsN di Kota Kendari berdasarkan asal sekolahnya (yakni MTsN 1 Kendari dan MTsN 2 Kendari). Analisis data pada bagian ini bertujuan untuk memberikan gambaran perbedaan kemampuan literasi matematis antara siswa di MTsN 1 kendari dengan siswa di MTsN 2 Kendari. Deskripsi terkait kemampuan literasi matematis siswa di kedua sekolah tersebut disajikan dalam bentuk tabel dan grafik.

Jika Kemampuan Literasi Matematis siswa kelas IX di MTsN 1 Kendari dan MTsN 2 Kendari dibagi menjadi kategori tinggi (Nilai $\geq$ mean $+0,5 \cdot$ Standar Deviasi), sedang (mean - 0,5·Standar Deviasi $\leq$ Nilai $<$ mean $+0,5 \cdot$ Standar Deviasi) dan rendah (mean $0,5 \cdot$ Standar Deviasi < Nilai), persentase kemampuan siswa dapat dilihat pada tabel 5 berikut:

Tabel 5; Persentase Kemampuan Literasi Matematis siswa di Madrasah Tsanawiyah Negeri (MTsN) 1 Kendari dan Madrasah Tsanawiyah Negeri (MTsN) 2 Kendari pada Tahun Ajaran 2018/2019

\begin{tabular}{ccccc}
\hline \multirow{2}{*}{ Kemampuan } & \multicolumn{4}{c}{ Sekolah } \\
\cline { 2 - 5 } & \multicolumn{2}{c}{ MTsN 1 Kendari } & \multicolumn{2}{c}{ MTsN 2 Kendari } \\
\cline { 2 - 5 } Tinggi & Jumlah Siswa & Persentase & Jumlah Siswa & Persentase \\
\hline Sedang & 24 & $39 \%$ & 11 & $18 \%$ \\
\hline Rendah & 17 & $34 \%$ & 21 & $34 \%$ \\
\hline Total & 62 & $27 \%$ & 29 & $48 \%$ \\
\hline
\end{tabular}

Dari tabel 5 diketahui bahwa jumlah siswa yang memiliki Kemampuan Literasi Matematis dengan kategori tinggi di MTsN 1 Kendari lebih banyak dibandingkan dengan siswa MTsN 2 Kendari, yakni siswa Madrasah Tsanawiyah Negeri 1 Kendari berjumlah 24 siswa dengan persentase 39\% dan siswa Madrasah Tsanawiyah Negeri 2 berjumlah 11 siswa dengan persentase $18 \%$. Kemudian siswa yang memiliki Kemampuan Literasi Matematis rendah di MTsN 1 Kendari lebih sedikit dibandingkan dengan siswa MTsN 2 Kendari, yakni siswa Madrasah Tsanawiyah Negeri 1 Kendari berjumlah 17 siswa dengan persentase 27\% dan siswa Madrasah Tsanawiyah Negeri 2 berjumlah 29 siswa dengan persentase $48 \%$. Sedangkan untuk siswa yang memiliki Kemampuan Literasi Matematis rendah di MTsN 1 Kendari berjumlah sama dengan siswa MTsN 2 Kendari, yakni siswa Madrasah Tsanawiyah Negeri 1 Kendari dan jumlah siswa Madrasah Tsanawiyah Negeri 2 Kendari berjumlah 21 siswa dengan persentase 34\%.

Karakteristik (nilai statistik) Kemampuan Literasi Matematis dari sampel siswa kelas IX MTsN untuk masing-masing berdasarkan level Soal Kemampuan Literasi Matematis nya dapat dilihat pada tabel 6 berikut:

Tabel 6; Karakteristik Kemampuan Literasi Matematis siswa per Level Kemampuan Literasi Matematis di MTsN Kendari 1 Kendari dan MTsN 2 Kendari Tahun Ajaran $2018 / 2019$

\begin{tabular}{lllllll}
\hline \hline Level & $\begin{array}{c}\text { Nilai } \\
\text { Maks }\end{array}$ & $\begin{array}{c}\text { Nilai } \\
\text { Min }\end{array}$ & Mean & Modus & Median & $\begin{array}{c}\text { Standar } \\
\text { Deviasi }\end{array}$ \\
\hline \hline
\end{tabular}


Al Izzah: Jurnal Hasil-Hasil Penelitian-ISSN: 1978-9726 (p); 2541-0717 (e)

Volume 14, Nomor 1 (Mei, 2019)

\begin{tabular}{cccccccccccccc}
\hline \hline & \multicolumn{1}{c}{$\begin{array}{c}\text { Skor } \\
\text { Maks } \\
\text { Soal }\end{array}$} & $\mathbf{1}$ & $\mathbf{2}$ & $\mathbf{1}$ & $\mathbf{2}$ & $\mathbf{1}$ & $\mathbf{2}$ & $\mathbf{1}$ & $\mathbf{2}$ & $\mathbf{1}$ & $\mathbf{2}$ & $\mathbf{1}$ & $\mathbf{2}$ \\
\hline \hline 1 & 10 & 9 & 9 & 2 & 3 & 7,2 & 7,7 & 8 & 8 & 8 & 8 & 1,6 & 1,19 \\
2 & 10 & 9 & 7 & 0 & 0 & 4,14 & 3,34 & 5 & 2 & 4 & 3 & 2,2 & 1,44 \\
3 & 15 & 14 & 8 & 0 & 0 & 5,47 & 3,78 & 5 & 3 & 5 & 3 & 3,48 & 2,36 \\
4 & 5 & 5 & 4 & 0 & 0 & 1,95 & 1,4 & 0 & 1 & 1 & 1 & 1,83 & 1,2 \\
5 & 5 & 5 & 4 & 0 & 0 & 1,16 & 1,4 & 1 & 0 & 1 & 1 & 1,5 & 1,6 \\
6 & 10 & 10 & 4 & 0 & 0 & 1.45 & 1.45 & 0 & 2 & 1 & 2 & 1,87 & 0,9 \\
\hline \hline
\end{tabular}

Berdasarkan Tabel 6 dapat diketahui bahwa, nilai maksimum siswa di MTsN 1 Kendari cenderung lebih tinggi dibanding siswa di MTsN 2 Kendari, terutama pada soal level 3 dan 6. Pada level soal tersebut, terdapat siswa di MTsN 1 Kendari memiliki nilai/skor perolehan yang sama dengan skor maksimum soal. Jika dilihat dari nilai rataratanya, rata-rata Kemampuan Literasi Matematis siswa di kedua sekolah tertinggi ditunjukkan oleh Kemampuan Literasi Matematis mereka di level 1 dan terendah ditunjukan oleh level 5 dan 6. Jika dilihat lebih lanjut lagi, nilai rata-rata Kemampuan Literasi Matematis siswa di MTsN 1 Kendari cenderung lebih tinggi dibanding siswa di MTsN 2 Kendari. Terutama soal dengan level 2, 3, 4, dan 5, sedangkan soal level 1 siswa di MTsN 2 masih lebih baik disbanding siswa di MTsN 1. Berdasarkan nilai standar deviasi yang menjelaskan seberapa jauh data skor Kemampuan Literasi Matematis menyimpang dari ukuran pemusatannya, dapat diketahui bahwa nilai standar deviasi Kemampuan Literasi Matematis Siswa, tertinggi untuk masing-masing sekolah diperoleh pada soal level 3. Hal ini menunjukkan bahwa Kemampuan Literasi Matematis siswa dalam menjawab soal level 3 memiliki keragaman nilai yang lebih besar dibanding dengan ketika menjawab soal level lainnya.

Diagram Rata-rata Persentase Kemampuan Literasi Matematis per Level soal Kemampuan Literasi Matematis Siswa di MTsN 1 Kendari dan Siswa di MTsN 2 Kendari, dapat dilihat pada diagram berikut ini:

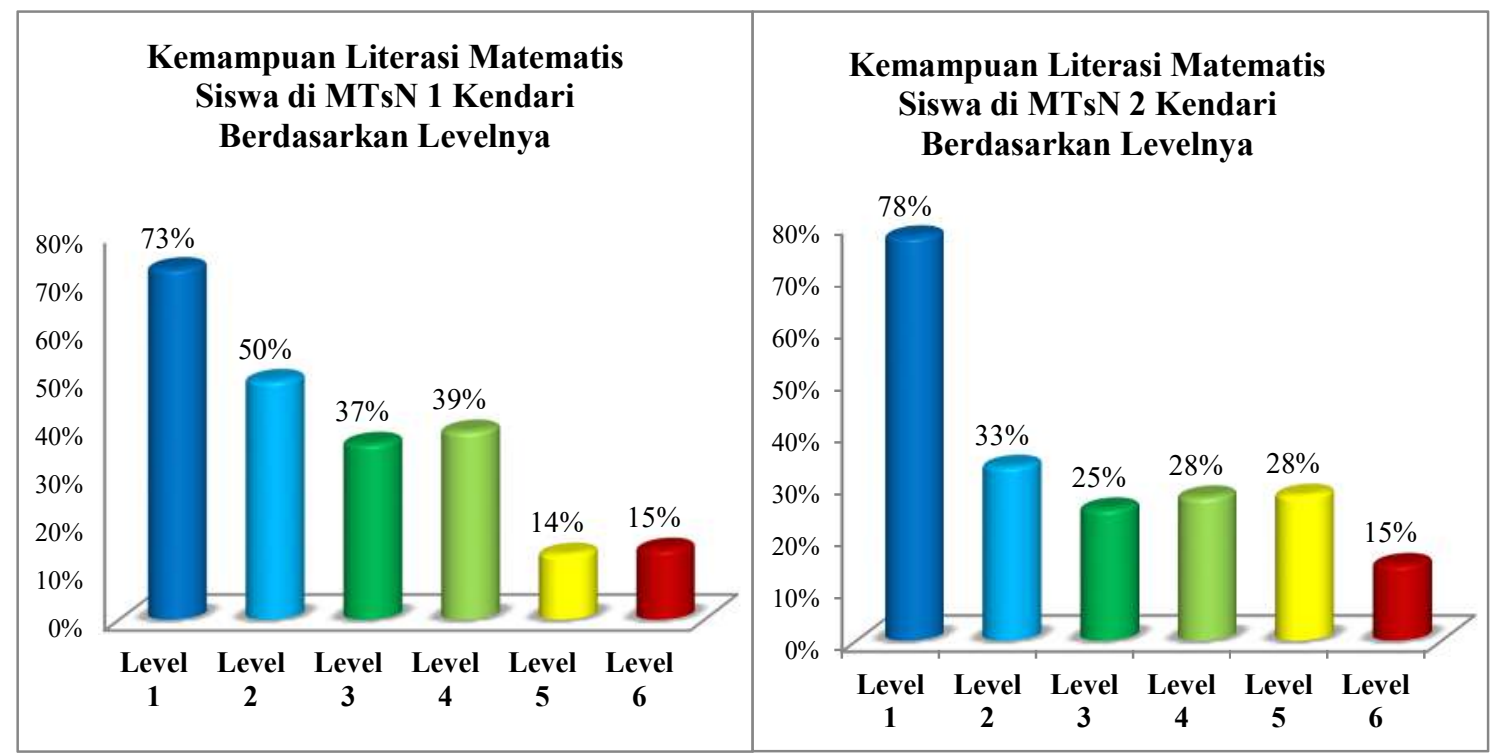


Gambar 5; Perbandingan Persentase Rata-Rata Kemampuan Literasi Matematis Berdasarkan Level Kemampuan Literasi Matematis

Berdasarkan Gambar 5 di atas, dapat dilihat bahwa rata-rata kemampuan Literasi Matematis siswa di MTsN 1 Kendari dan MTsN 2 Kendari pada level 1 masing sebesar $73 \%$ dan $78 \%$ dari total skor maksimal yang diharapkan, atau dengan kata lain siswa MTsN di Kota Kendari mampu menyelesaikan soal level 1 Kemampuan Literasi Matematis dengan rata-rata keseluruhan sebesar 7,3 pada MTsN 1 Kendari lebih rendah dibanding siswa pada MTsN 2 Kendari yang memperoleh rata-rata sebesar 7,8 dari total skor yang diharapkan yakni sebesar 10. Pada level 2 rata-rata Kemampuan Literasi Matematis siswa MTsN 1 Kendari 17\% lebih tinggi dibandingkan dengan rata-rata Kemampuan Literasi Matematis siswa di MTsN 2 Kendari. Pada level 3 rata-rata Kemampuan Literasi Matematis siswa MTsN 1 Kendari 12\% lebih tinggi dibandingkan dengan rata-rata Kemampuan Literasi Matematis siswa di MTsN 2 Kendari. Pada level 4 rata-rata Kemampuan Literasi Matematis siswa MTsN 1 Kendari 11\% lebih tinggi dibandingkan dengan rata-rata Kemampuan Literasi Matematis siswa di MTsN 2 Kendari. Pada level 5 rata-rata Kemampuan Literasi Matematis siswa MTsN 1 Kendari 14\% lebih rendah dibandingkan dengan rata-rata Kemampuan Literasi Matematis siswa di MTsN 2 Kendari. Pada level 6 rata-rata Kemampuan Literasi Matematis siswa MTsN 1 Kendari memiliki rata-rata yang sama dengan rata-rata Kemampuan Literasi Matematis siswa di MTsN 2 Kendari yakni masing-masing sekolah memiliki rata-rata sebesar 15\%. Hasil ini menjelaskaan bahwa secara keseluruhan rata-rata persentase Kemampuan Literasi Matematis siswa Kelas IX MTsN 1 Kendari pada tiap levelnya lebih baik disbanding dengan siswa Kelas IX di MTsN 2 Kendari.

Karakteristik (nilai statistik) Kemampuan Literasi Matematis dari sampel siswa kelas IX MTsN untuk masing-masing berdasarkan konten soalnya dapat dilihat pada tabel 7 berikut:

Tabel 7; Karakteristik Kemampuan Literasi Matematis Siswa per Konten Kemampuan Literasi Matematis di Madrasah Tsanawiyah Negeri 1 Kendari

\begin{tabular}{|c|c|c|c|c|c|c|c|c|c|c|c|c|c|}
\hline \multirow{3}{*}{ Konten } & \multirow{3}{*}{$\begin{array}{c}\text { Skor } \\
\text { Maks } \\
\text { Soal }\end{array}$} & \multicolumn{2}{|c|}{$\begin{array}{l}\text { Nilai } \\
\text { Maks } \\
\end{array}$} & \multicolumn{2}{|c|}{$\begin{array}{l}\text { Nilai } \\
\text { Min }\end{array}$} & \multicolumn{2}{|c|}{ Mean } & \multicolumn{2}{|c|}{ Modus } & \multicolumn{2}{|c|}{ Median } & \multicolumn{2}{|c|}{$\begin{array}{l}\text { Standar } \\
\text { Deviasi }\end{array}$} \\
\hline & & \multicolumn{12}{|c|}{ MTs Negeri } \\
\hline & & 1 & 2 & 1 & 2 & 1 & 2 & 1 & 2 & 1 & 2 & 1 & 2 \\
\hline 1 & 15 & 14 & 9 & 3 & 3 & 9,2 & 7,75 & 9 & 8 & 9 & 8 & 2,32 & 1,19 \\
\hline 2 & 20 & 19 & 10 & 0 & 1 & 5,7 & 4,21 & 5 & 4 & 3 & 4 & 3,72 & 2,13 \\
\hline 3 & 10 & 8 & 5 & 0 & 0 & 3,93 & 2,88 & 4 & 2 & 4 & 2 & 1,97 & 1,6 \\
\hline 4 & 10 & 10 & 9 & 0 & 0 & 4,64 & 3,52 & 5 & 2 & 0 & 2 & 3,38 & 2,54 \\
\hline
\end{tabular}

Dari Tabel 7 dapat diketahui bahwa, nilai maksimum siswa di MTsN 1 Kendari cenderung lebih tinggi dibanding siswa di MTsN 2 Kendari. Bahkan pada konten 4, terdapat siswa di MTsN 1 Kendari memiliki nilai/skor perolehan yang sama dengan skor maksimum soal. Hal ini menunjukkan bahwa pada soal yang berkaitan dengan perubahan dan keterkaitan (change and relationship) terdapat siswa di MTsN 1 Kendari yang memiliki kemampuan literasi yang sangat baik, dan lebih baik dibanding dengan siswa di MTsN 2 Kendari. Jika dilihat dari nilai rata-ratanya, rata-rata Kemampuan Literasi 
Matematis siswa di kedua sekolah tertinggi ditunjukkan oleh Kemampuan Literasi Matematis mereka soal berkonten 1 yaitu soal yang berkaitan dengan ketidakpastian dan data (uncertainty and data) dan terendah ditunjukan oleh soal dengan konten 3 yakni kuantitas (quantity). Jika dilihat lebih lanjut lagi, nilai rata-rata Kemampuan Literasi Matematis siswa di MTsN 1 Kendari berdasarkan konten soalnya cenderung lebih tinggi dibanding siswa di MTsN 2 Kendari. Terutama soal dengan konten 1. Berdasarkan nilai standar deviasi yang menjelaskan seberapa jauh data skor Kemampuan Literasi Matematis menyimpang dari ukuran pemusatannya, dapat diketahui bahwa nilai standar deviasi Kemampuan Literasi Matematis Siswa, tertinggi untuk masing-masing sekolah diperoleh pada soal berkonten 2 yaitu konten ruang dan bentuk (space and shape) dan 4 yaitu konten perubahan dan keterkaitan (change and relationship). Hal ini menunjukkan bahwa Kemampuan Literasi Matematis siswa dalam menjawab soal berkonten 2 dan 4 memiliki keragaman nilai yang lebih besar dibanding dengan ketika menjawab soal dengan konten yang lainnya.

Selanjutnya untuk mengetahui perbedaan rata-rata kemampuan literasi matematis siswa di masing-masing sekolah per konten soal Kemampuan Literasi Matematis Siswa di MTsN 1 Kendari dan MTsN 2 Kendari, dapat dilihat pada diagram berikut ini:

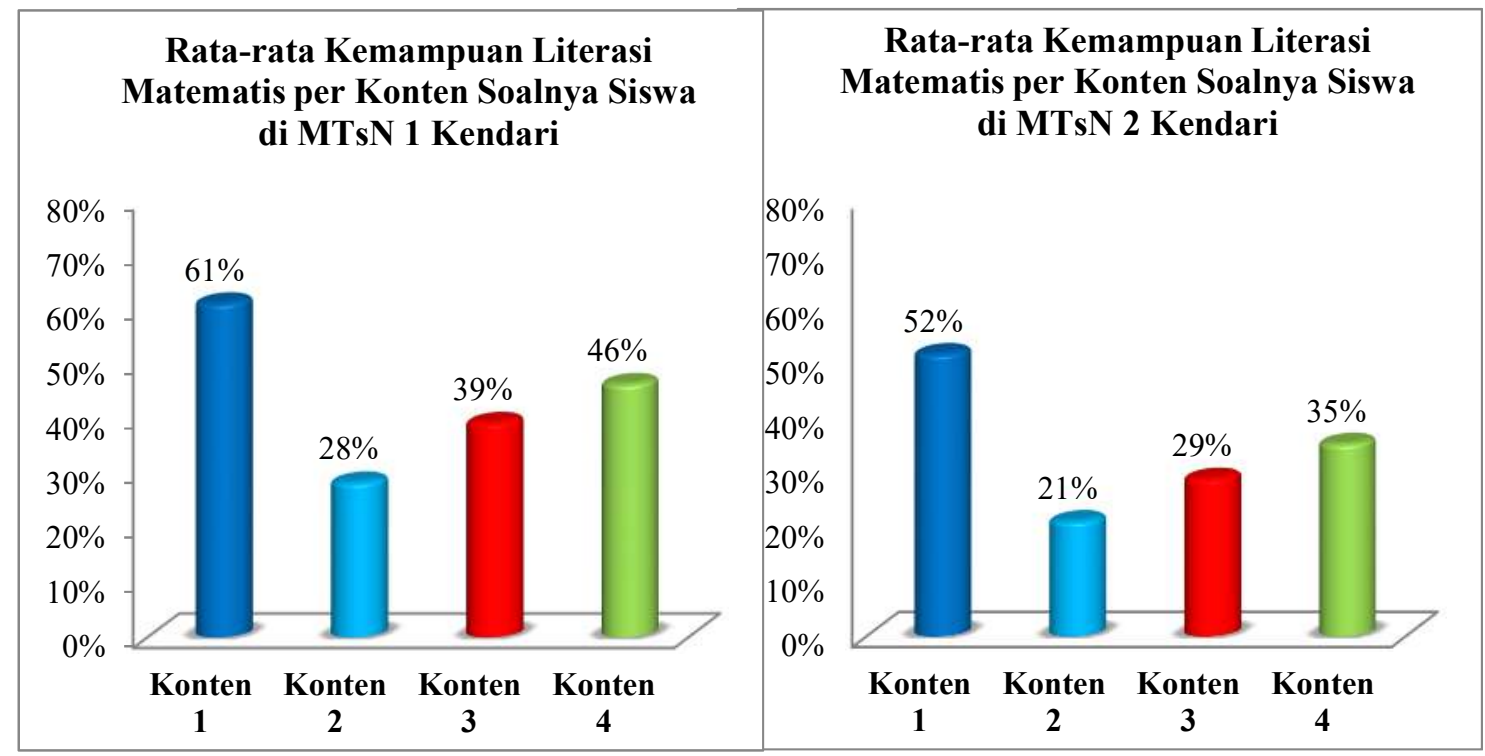

Gambar 6; Perbandingan Persentase Rata-Rata Kemampuan Literasi Matematis Berdasarkan Kontennya

Berdasarkan Gambar di atas dapat dilihat bahwa rata-rata kemampuan Literasi Matematis siswa di MTsN 1 Kendari dan MTsN 2 Kendari pada soal konten 1 masing sebesar $61 \%$ dan $52 \%$ dari total skor maksimal yang diharapkan, atau dengan kata lain siswa MTsN di Kota Kendari mampu menyelesaikan soal konten 1 Kemampuan Literasi Matematis dengan rata-rata keseluruhan sebesar 6,1 pada MTsN 1 Kendari lebih tinggi dibanding siswa pada MTsN 2 Kendari yang hanya memperoleh rata-rata sebesar 5,2 dari total skor yang diharapkan yakni sebesar 10. Pada konten 2 rata-rata Kemampuan Literasi Matematis siswa MTsN 1 Kendari 7\% lebih tinggi dibandingkan dengan rata-rata Kemampuan Literasi Matematis siswa di MTsN 2 Kendari. Pada konten 3 rata-rata Kemampuan Literasi Matematis siswa MTsN 1 Kendari 10\% lebih tinggi dibandingkan 


\section{Al Izzah: Jurnal Hasil-Hasil Penelitian-ISSN: 1978-9726 (p); 2541-0717 (e) \\ Volume 14, Nomor 1 (Mei, 2019)}

dengan rata-rata Kemampuan Literasi Matematis siswa di MTsN 2 Kendari. Pada konten 4 rata-rata Kemampuan Literasi Matematis siswa MTsN 1 Kendari 14\% lebih tinggi dibandingkan dengan rata-rata Kemampuan Literasi Matematis siswa di MTsN 2 Kendari. Dengan demikian, dilihat dari level maupun konten soalnya, kemampuan literasi matematis siswa kelas IX di MTsN 1 Kendari lebih baik dibanding siswa kelas IX di MTsN 2 Kendari.

\section{PENUTUP}

Secara keseluruhan, persentase kemampuan literasi matematis siswa MTsN Kota Kendari masih didominasi oleh kelompok siswa yang berkemampuan rendah. Berdasarkan kontennya, kemampuan litearasi matematis siswa masih rendah pada konten 2. Tetapi, jika dilihat berdasarkan pengkategoriannya, Siswa dengan kategori Kemampuan Literasi Matematis yang rendah lebih banyak terdapat pada konten 4 yaitu Perubahan dan Keterkaitan. Ini berarti, siswa sulit untuk menyelesaikan soal-soal pada kategori Perubahan dan keterkaitan seperti soal-soal perbandingan dan aljabar. Jika dilihat berdasarkan levelnya, siswa memperoleh nilai paling rendah pada soal-soal level 6 . Namun, jika dilihat berdasarkan pengkategoriannya, siswa dengan kategori Kemampuan Literasi Matematis rendah lebih banyak terdapat pada soal level 2 dan level 4. Dengan membandingkan Kemampuan Literasi Matematis siswa pada dua sekolah yang dijadikan objek penelitian diperoleh bahwa baik berdasarkan konten maupun levelnya, kemampuan literasi matematis siswa kelas IX MTsN 1 Kendari lebih baik dibandingkan siswa kelas IX MTsN 2 Kendari. 


\section{Daftar Pustaka}

Abidin, Y., Tita Mulyati, dan Hana Yunansah. Pembelajaran Literasi, Strategi Meningkatkan Kemampuan Literasi Matematika, Sains, Membaca, dan Menulis. (Jakarta: Bumi Aksara, 2018). 99.

Hendriana, Heris dan Utari Soemarmo, Penilaian Pembelajaran Matematika, (Bandung: PT. Refika Aditama, 2014), 19.

Khoirudin, A., Rina Dwi Setyawati, dan Farida Nuryahida. "Profil Kemampuan Literasi Matematika Siswa Berkemampuan Matematis Rendah Dalam Menyelesaikan Soal Berbentuk PISA”. Aksioma, Vol. 8, No. 2, (November, 2017): 39.

Maulana, Agus dan Hasnawati. "Deskripsi Kemampuan Literasi Matematika Siswa Kelas VIII2 SMP Negeri 15 Kendari”. Jurnal Pendidikan Matematika. Volume 4, No. 2, (Mei, 2016): 3 .

Mahdiansyah dan Rahmawati. "Literasi Matematika Siswa Pendidikan Menengah: Analisis Menggunakan Desain Tes Internasional dengan Konteks Indonesia”. Jurnal Pendidikan dan Kebudayaan. Vol. 20, Nomor 4, (Desember, 2014): 454.

Masjaya dan Wardono. "Pentingnya Kemampuan Literasi Matematika untuk Menumbuhkan Kemampuan Koneksi Matematika dalam Meningkatkan SDM". Prosiding dipresentasikan dalam Seminar Nasional Matematika UNNES 2017, Semarang, 21 Oktober 2017.

Mullis, I. V.S., Michael O. Martin, Pierre Foy, dan Martin Hooper, TIMSS 2015 International Result in Mathematics. (IEA TIMSS \& PIRLS International Study Center, 2015), 14.

OECD. Mathematics Framework: Draft Subject to Possible revision after the Field Trial. (OECD, 2010): 27.

OECD. PISA 2015 Result in Focus. (OECD, 2016). 16.

Prabawati, Mega Nur. "Analisis Kemampuan Literasi Mtematik Mahasiswa Calon Guru matematika". Jurnal "Mosharafa". Volume 7, Nomor 1,( Januari, 2018): 114.

Qasim, Kadir dan Awaluddin. "Deskripsi Kemampuan Literasi Matematika Siswa SMP Negeri di Kabupaten Buton Utara”. Jurnal Penelitian Pendidikan Matematika. Volume 3, No. 3. (Mei, 2015): 98.

Siswowijoyo, Mia dan Kadir Tiya. "Deskripsi Kemampuan Literasi Matematika Siswa Kelas IX SMP Negeri di Kota Raha". Jurnal Penelitian Pendidikan Matematika. Volume 2, No. 2. (Mei, 2014): 84-85.

Susanti, Elsa dan Slamaini Safitri Syam. "Peran Guru dalam Meningkatkan Kemampuan Literasi Matematika Siswa Indonesia". Prosiding dipresentasikan dalam Seminar Matematika dan Pendidikan Matematika UNY 2017. Yogyakarta, 11 Nopember 2017. 